Striking Out 


\section{Critical Texts in Social Work and the \\ Welfare State \\ General Editor: Peter Leonard \\ Published}

Pete Alcock and Phil Harris: WELFARE LAW AND ORDER

Ragnhild Banton, Paul Clifford, Stephen Frosh, Julian Lousada, Joanna

Rosenthall: THE POLITICS OF MENTAL HEALTH

Paul Corrigan and Peter Leonard: SOCIAL WORK PRACTICE UNDER CAPITALISM: A MARXIST APPROACH

Ian Gough: THE POLITICAL ECONOMY OF THE WELFARE STATE

Chris Jones: STATE SOCIAL WORK AND THE WORKING CLASS

Paul Joyce, Paul Corrigan, Mike Hayes: STRIKING OUT: SOCIAL WORK AND TRADE UNIONISM, 1970-85

Peter Leonard: PERSONALITY AND IDEOLOGY: TOWARDS A MATERIALIST UNDERSTANDING OF THE INDIVIDUAL

Chris Phillipson: CAPITALISM AND THE CONSTRUCTION OF OLD AGE

$$
\text { Forthcoming }
$$

Lena Dominelli and Eileen McLeod: FEMINIST SOCIAL WORK

Peter Leonard: A GRITICAL HISTORY OF SOCIAL WORK THEORY

Mike Oliver: THE POLITICS OF DISABLEMENT

Goran Therborn: WELFARE STATES AND ADVANCED CAPITALISM

\section{Series Standing Order}

If you would like to receive future titles in this series as they are published, you can make use of our standing order facility. To place a standing order please contact your bookseller or, in case of difficulty, write to us at the address below with your name and address and the name of the series. Please state with which title you wish to begin your standing order. (If you live outside the United Kingdom we may not have the rights for your area, in which case we will forward your order to the publisher concerned.)

Customer Services Department, Macmillan Distribution Ltd Houndmills, Basingstoke, Hampshire, RG21 2XS, England. 


\title{
Striking Out
}

\section{Trade Unionism in Social Work}

\author{
Paul Joyce, Paul Corrigan \\ and Mike Hayes
}

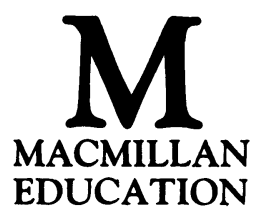


(C) Paul Joyce, Paul Corrigan and Mike Hayes 1988 Foreword (C) Peter Leonard 1988

All rights reserved. No reproduction, copy or transmission of this publication may be made without written permission.

No paragraph of this publication may be reproduced, copied or transmitted save with written permission or in accordance with the provisions of the Copyright Act 1956 (as amended), or under the terms of any licence permitting limited copying issued by the Copyright Licensing Agency, 33-4 Alfred Place, London WC1E 7DP.

Any person who does any unauthorised act in relation to this publication may be liable to criminal prosecution and civil claims for damages.

First published 1988

\author{
Published by \\ MACMILLAN EDUCATION LTD \\ Houndmills, Basingstoke, Hampshire RG21 2XS \\ and London \\ Companies and representatives \\ throughout the world
}

British Library Cataloguing in Publication Data

Joyce, Paul, 1952-

Striking out : trade unionism in

social work. - (Critical texts in

social work and the welfare state).

1. Social service - Great Britain

2. Trade-unions - Great Britain

I. Title II. Hayes, Mike III. Corrigan,

Paul IV. Series

361.3'0941 HV245

ISBN 978-0-333-38816-7

ISBN 978-1-349-19182-6 (eBook)

DOI 10.1007/978-1-349-19182-6 


\section{Contents}

List of Tables vi

Acknowledgements vii

Editor's Foreword viii

Introduction 1

PART I THEORIES 13

1 Theories of Trade Unionism 15

PART II ISSUES FACING TRADE UNIONISM IN SOCIAL WORK 35

Introduction $\quad 37$

2 Radicalism and Sectionalism 43

3 Rank-and-Filism and the Need for Alliances 95

4 Trade Unionism and the Struggle for Municipal Socialism - Progressive Practice in Reactionary Times

PART III THEORY, POLITICS AND PROGRAMME

5 Making Sense of History 195

6 Democracy and the Public Sector 228

7 A Programme for Social Workers' Trade Unionism

Bibliography 285

Index 289 


\section{List of Tables}

1.1 Types of theory of trade unionism

1.2 An inter-sectoral comparison of British trade unionism

2.1 Decision-making in the hierarchy

2.2 Non-manual social services workforce in English and Welsh local authorities, 1984

3.1 Payments from NALGO's special reserve fund 119

4.1 Public expenditure planning totals

4.2 Net current expenditure at Leeds City Council 167

4.3 Number of staff at Leeds City Council 167

4.4 Expenditure on personal social services, 1983-84 179

4.5 Money and real salaries of social workers, 1970-85 186

4.6 National distribution of social workers on pay scales, 1980-84

4.7 Local government and social services staffing in England and Wales, 1979-84 


\section{Acknowledgements}

Over the years, many trade unionists in social services departments have helped us by agreeing to talk about their experiences and perceptions. Because of their generosity, we have been in a position to analyse the particular circumstances of, and developments in, social work trade unionism. Many of the quotations in this book, which have been taken from our conversations with them, testify to the rich and vigorous ideas and arguments which have informed social work trade unionism. We would like to thank them all for their patience and kindness.

The final structure and arguments of this book owe a great deal to the comments and criticisms of Peter Leonard, the editor, and Steven Kennedy at Macmillan. We are also grateful for the helpful criticisms of an anonymous reviewer, whose suggestions and comments led to a number of changes. Of course, any faults or weaknesses that persist are entirely due to us.

We would also like to thank Lucy McAuley, who typed the manuscript. And, inevitably, we must acknowledge the essential support of family and friends. 


\section{Editor's Foreword}

To be both a social worker and a trade union activist in the late 1980s is to experience defeat at almost every turn. Major structural changes are under way in British society of a kind which would be unimaginable even in the 1970s. Under the leadership of a determined and ruthless right-wing government radical change is taking place in many of the institutions, policies and practices which were established as a result of the long struggles of the Labour movement during this century. Although battles continue to be fought, the terrain is increasingly defined by a white male ruling class which every day shows its contempt for both trade unions and welfare services and has the capacity and ideological clarity to act upon these deep-seated emotions.

The consequences of this historic crisis for the Labour movement, for feminists, for anti-racists and for other progressive forces are profound. It is not difficult to sink into despair when faced with such a decisive shift in class forces, a shift which is designed to be permanent, leaving Britain with a social and cultural order dominated by a market liberalism fashioned to the management of a declining economy and massive unemployment. The superstructural characteristics of this new order are a strong authoritarian central state apparatus, a profoundly weakened local government and a minimal level of public sector health and social services grudgingly provided for the poorest and most defenseless segments of the population. Such a society, all the elements of which are already in place, requires, as a major precondition, the termination of a strong trade union movement which would otherwise be a significant source of resistance.

One alternative to despair and disillusionment is to engage in a critical, often painful, re-examination of the assumptions 
upon which the political practices of the Left have long been based. Have the material conditions which generated past political struggles changed to a degree which requires completely new forms of practice? Has the class structure of our society undergone such transformations as to demand a rethinking of the most basic taken-for-granted assumptions about 'the class', its composition, and its role in future political struggle? Can the forces of the Left so transform themselves that they can simultaneously confront the oppression of gender, racism and class without destructively prioritising one over the others?

For social work trade unionists, the present political crisis and the questions which it raises point to very specific dilemmas. As the central state becomes more authoritarian in its attempt, aided by media-assisted moral panics, to control 'deviant' populations and victimise social workers for the devastating results of structural inequalities, where does one turn for support, for defensive cover, for collective action?

Two possibilities have presented themselves. One is to turn to professionalism and to professional associations as the ground upon which to stand and demand a degree of autonomy in relation to state power and present the challenge of liberal professional values against punitive social policies. But social work professionalism, even when it has been at its most progressive, has proved to be too weak on its own to withstand prolonged assault. The radical Right has little patience with liberal professionalism, seeing it as an interference with costeffective management and as one reason why social workers are difficult employees.

The second possibility, not necessarily incompatible with the first, is to turn to active trade union work, to militancy, as the means by which the particular needs of social workers, and possibly their welfare clients, can be most effectively defended. Here again, many problems have presented themselves. What kind of trade unionism is most appropriate to public service workers has been the source of many debates, and for social workers within NALGO has always been seen as difficult issue. As professionals engaged in a labour process which, despite contradictions, produces concrete benefits for people, the traditional model of trade unionism has been often 
experienced as ineffective. Industrial action involving the withdrawal of labour has invariably been a painful process, full of personal conflicts for social workers and problems for at least some welfare consumers.

These issues, and many similar ones, lie at the core of Striking Out. The authors grasp hold of the essential dilemmas of social work trade unionism and have produced an extremely important book, critical to the political situation of the last years of the 1980s and I believe the beginning of the 1990s. Based upon a foundation of empirical research, the book places social work trade unionism in the context of manual and white-collar unionism and charts its history in the 1970 s and 1980s. The result is a book which uses history to ask central theoretical and political questions, and it is this which makes it so impressive. The most important question which is raised by this book has to do with the need for different sections of the trade union movement to develop forms of struggle most appropriate to their particular conditions. On the basis of careful analysis, Paul Joyce, Paul Corrigan and Mike Hayes argue that social work trade unionism during the 1970 s and early 1980s made the mistake of adopting forms of struggle appropriate to other more traditional parts of the trade union movement and that it became, for a time, vanguardist and sectional in its whole approach to industrial relations. Such an approach, though understandable, failed to take full account of the contradictions within social work practice - its oppressive and beneficial elements - the particular nature, in other words, of the labour processes of social workers.

Because this is an intensely political book, reflecting the author's commitment to both trade unionism and progressive forms of social work, the research, the questioning and the analysis leads, towards the end of the book, to a set of practical proposals for the way forward for social work trade unionism.

This is bound to be an extremely controversial book, especially so far as the Left is concerned. Arguments will be especially fierce over the problems and possibilities of "rankand-file' militancy and over the likelihood of large trade union organisations ever becoming political instruments for progressive change in the present historical period. Debates amd 
arguments over the issues raised by this book and the solutions offered, the attempt to 'learn from history', are of central importance at the present time. This is a book which looks at our recent history, including the experiences of defeat, in a non-defeatist way. It is what we need now.

McGill University

PETER LEONARD 